\title{
Research on Training System of Young Teachers in Education Management of Colleges and Universities*
}

\author{
Wei Wang \\ Wuhan Donghu University \\ Wuhan, China 430212
}

\begin{abstract}
With the leapfrog development of higher education in China, young teachers have become an important group in college teachers. Young teachers in colleges and universities have the dual identities as teachers and young talents. The participation of young teachers in education management reflects the essential requirements that the purpose of higher education in China is to strengthen moral education and cultivate people, embodies the essential attributes of colleges and universities in China and has the special superiority. Therefore, colleges and universities should base on the study of the realistic problems and shortcomings of young teachers' participation in education management, explore the construction of long-term and scientific evaluation and guarantee institution and mechanism of young teachers' participation in education management, and train and encourage young teachers to actively participate in the education management work of colleges and universities, so as to achieve sustainable and healthy development of higher education.
\end{abstract}

Keywords-education management; young teachers; colleges and universities; system

\section{INTRODUCTION}

$\mathrm{Xi}$ Jinping clearly points out that "the foundation of the colleges and universities is to strengthen moral education and cultivate people. Only a university that has developed topnotch talents can rank in the world. To run a good university in China and to establish a world-class university, we must firmly grasp the core point of comprehensively improving the ability of talent cultivation, and use this to drive other work in colleges and universities." 1 Young teachers in colleges and universities have the dual identities as teachers and young talents. They not only shoulder the professional mission of teaching and educating people, and at the same time they are also important objects of talent cultivation of colleges and universities. "The younger generation has ideals, skills, and responsibility. The country has a future, and the nation has

*Project: Research on New Media Approach of Socialist Ecological Civilization Education with Chinese Characteristics of youth fund funding project of Wuhan Donghu University

Project number: 2017 dhsk 008.

Xi Jinping. Put ideological and political work through the whole process of education and teaching and create a new situation in the development of higher education in China [N]. People's Daily, 2016-12-09. hope." ${ }^{2}$ Young teachers are the hard core of the future development of China's higher education. Constructing a scientific training system for young teacher and allowing young teachers to better participate in the education management work of colleges and universities not only reflects the objective demands of the development of China's colleges and universities, but also represents the Party's objective demands for representing, winning and relying on young people.

\section{THE NECESSITY OF YOUNG TEACHERS' PARTICIPATION IN EDUCATION MANAGEMENT OF COLLEGES AND UNIVERSITIES}

In recent years, with the leapfrog development of higher education in China, the size of teaching staff in colleges and universities in increasingly to expand. Among them, the development of young teachers is particularly evident. According to the statistics of the Ministry of Education, the number of young teachers under 40 years old in colleges and universities in China has exceeded 0.89 million, accounting for $55.80 \%$ of the total number of full-time teachers in colleges and universities all over the country. Young teachers have become an important group and have become the hard core of the future development of colleges and universities. In colleges and universities, young teachers have the dual identities as educators and educates, which determines that the growth and development of young teachers is not only an important condition for the sustainable and healthy development of colleges and universities in China, but also the growth of young teachers has significant influence on the realization of the development level of higher education and the goal of talent training in China.

\section{A. The Participation of Young Teachers in Education} Management of Colleges and Universities Reflects the Education Demands That Colleges and Universities Strengthen Moral Education and Cultivate People

In China, the foundation of higher education is to strengthen moral education and cultivate people. To run a good university in China and to establish a world-class university,

Xi Jinping. Secure a Decisive Victory in Building a Moderately Prosperous Society in All Respects and Strive for the Great Success of Socialism with Chinese Characteristics for a New Era-Delivered at the 19th National Congress of the Communist Party of China [N]. People's Daily, 2017-10-28. 
we must firmly grasp the core point of comprehensively improving the ability of talent cultivation and use this to drive other work in colleges and universities. Therefore, strengthening moral education and cultivating people and imparting knowledge and educating people is the foundation of all the work of the university. College teachers, no matter which subject or major they belong to, whether they are in classroom teaching or practical teaching, need to undertake the dual functions of moral education and intellectual education. Therefore, young teachers must assume the responsibilities as the guider and mentor to instruct them to grow up, and at the same time they should play their role in the innovative development of college education management. Through exercise and training in various forms and different positions, it can help young teachers to "adhere to the unity of teaching and education, stick to the unity of teaching by personal example as well as verbal instructions, persist in the unity of doing research and paying attention to society, and keep to the unity of academic freedom and academic norms, and guide most teachers to conduct, do research and teach with morality." 3

\section{B. The Participation of Young Teachers in Education Management of Colleges and Universities Is to Strengthen the Party's Requirements for College Leaders}

The leadership of the Party is an essential feature of Chinese universities, therefore, the growth of young teachers is inseparable from the leadership of the Party. As socialism with Chinese characteristics enters into a new era, with the development of information technology and the rise of new media, contemporary youths have presented new characteristics of times. Their positive thinking, broad vision and confidence make today's young people actively and broadly involved in various social activities. They are innovative and creative, and have ability to drive today's young people to contribute to the advancement of China in a powerful and creative way. Young teachers are the outstanding representatives and an important part of contemporary youths. Strengthening the Party's leadership for young teachers in colleges and universities and allowing young teachers grow up healthily is the specific requirements for strengthening the leadership of the Party in colleges and universities, which directly affects the realization of the essential attributes of higher education in China. It is the important content of the Party's youth work in colleges and universities that allows young teachers participate in the education and management of colleges and universities, better wining young teachers of colleges and universities and getting the future of the Party and country.

\section{The Participation of Young Teachers in Education Management of Colleges and Universities Has Special Advantages}

In the current cultivation system of talents of colleges and universities in China, young teachers in colleges and universities have similar ages, experiences and discourse

Xi Jinping. Put ideological and political work through the whole process of education and teaching and create a new situation in the development of higher education in China [N]. People's Daily, 2016-12-09. systems with students, therefore, they have more special advantages in the education management. Young teachers have more contact with students, and have more understanding on the actual life, practical learning, and practical thinking of students, and can carry out teaching work in a targeted method. In the reform of the education management system, young teachers can launch educational reform measures that students like to see and hear according to their demands of growth and talent. Especially in the current rapid development of new media, young teachers and students have commonality in the acceptance and use of new media. Through effective network interaction and online teaching, it can better realize the ideological resonance between teachers and students in teaching and management, reduce communication costs and improve the quality of teaching.

\section{The Existing Problems That Young Teachers PARTICIPATE IN EDUCATION MANAGEMENT OF COLLEGES AND UNIVERSITIES}

In recent years, in the process of strengthening and improving the education and teaching work of colleges and universities, China has paid more and more attention to the training and construction of young teaching staff. The Organizing Department, Propaganda Department, Ministry of Education of the Central Committee of the Communist Party of China have successively and jointly issued guidance documents on strengthening the construction of young teaching staff in colleges and universities. ${ }^{4}$ Some colleges and universities have started from "satisfying the needs and expectations of students' growth and development", and have taken a series of explorations on young teachers' participation in higher education and teaching management in the aspects that young teachers hold the post of administrative management positions and class teachers, and formed related supporting policies of teaching and management experience in the assessment and professional title appraisal of young teachers. However, as for how young teachers participate in the education management of colleges and universities, there is no relevant top-level design at present, which makes it difficult to form a sound system and mechanism and is hard to achieve systematization and popularization. In addition, as a whole, young college teachers have strong business abilities and learning attitudes, but some young teachers are limited by their own learning and practical work, and still have deviation of conception in different degrees for their role in imparting knowledge and educating people and strengthening moral education and cultivating people, and even some teachers' sense of mission and responsibility needs to be strengthened.

At present, there are some bottleneck problems that need to be solved for young teachers to participate in the education management of colleges and universities, mainly shown in the following aspects. First, teachers' enthusiasm needs to be improved. As a new force in the front line of teaching and scientific research in colleges and universities, young teachers'

Opinions on Strengthening the Construction of Young Teachers in Colleges and Universities issued by Ministry of Education, Organization Department, Propaganda Department, National Development and Reform Commission, Ministry of Finance, Ministry of Human Resources and Social Security of the People's Republic of China. [Z]. Teachers. No.10[2012]. 
age and social status have determined that they stay in a period of relatively large working pressure and living burden. Therefore, for position promotion, business assessment, and other problems that relate to their vital interests, in case there is not much correlation with participating in the education management of colleges and universities, the time and energy of young teachers' participation in education management is hardly guaranteed. For the education and teaching management work and their own teaching and scientific research work, many young teachers often choose the latter, therefore, they are often absent-minded when participating in education management work. Second, the content needs to be further clarified. At present, the specific content of young teachers' participation in university management is not clear enough, and their job responsibilities are not clear. The cultivation and growth of young teachers cannot be truly placed in the most important position. In the specific work, there are requirements in education management participation, and no goals in work. Third, the assessment and incentive mechanism needs to be improved. At present, the selecting institution and mechanism of teachers participating in school's education management has not yet been established, and examination and evaluation method of young teachers participating in education management work are still not sound, especially, there is no incentive mechanism linked to the promotion of the title of young teachers. Therefore, Young teachers are not interested in participating in the education management of higher education.

The most important reason for the above problems is that the incentive and guarantee system for young teachers to participate in the education management of colleges and universities has not been formed currently. First, the impact and incentive of the external environment are not strong. At present, affected by the strategy of rejuvenating China through science and education and strengthening China through talents, a growing number of young teachers in colleges and universities have regarded their careers as experts and scholars. Additionally, to a certain extent, many colleges and universities have the phenomenon of putting more emphasis on imparting knowledge rather than educating people, paying more attention to scientific research rather than teaching. In order to improve the academic prestige and ranking of the university, many colleges and universities often lay more emphasis on scientific research rather than teaching and practice. This reality has a negative impact on young teachers' devotion themselves to education management in colleges and universities. Moreover, many young teachers themselves still have limited abilities. The teacher himself first must understand the doctrine and believe it. The quality of young teachers is the premise and foundation for their devotion to education management. In order to publish articles and monographs, win post promotion, and increase income, some young teachers just pat attention to their own filed. For the newest achievements of national development, the newest policies of educational development, the newest spirits of school management and the newest changed thoughts of students, they cannot keep pace with the times, which caused that it is difficult for many young to participate in the education management of colleges and universities.

\section{COUNTERMEASURES AND ANALYSIS OF YOUNG TEACHERS' PARTICIPATION IN THE CONSTRUCTION OF EdUCATION MANAGEMENT TRAINING SYSTEM IN COLLEGES AND UNIVERSITIES}

As socialism with Chinese characteristics enters into the new era, the education management in colleges and universities requires the participation of young teachers. We need to seriously study the status quo of young teachers' participation in the education management in colleges and universities, construct a training system for young teachers, and foster young teachers' education idea of strengthening moral education and cultivating people, so as to make them consciously assume the duties and missions endowed by history and become participants and backbone of education management in colleges and universities.

\section{A. Improving the Long-term Mechanism of the Training System for Young Teachers}

To give full play to the unique advantages of young teachers in the education management in colleges and universities, it is necessary for universities to formulate scientific and clear long-term mechanisms. First of all, we should give play to the excellent young teachers' age advantages of staying close to students' life and ideological reality, and academic advantages of being in the front line of teaching and scientific research. Through scientific and rational teaching and management design, young teachers play an exemplary role and guide students and cultivate students' correct outlook on life and values. In addition, we must regard the education management in colleges and universities as the training platform for young teachers, broaden young teachers' vision, and cultivate and create a group of outstanding young teachers who are good at teaching and scientific research and familiar with teaching management. In order to achieve this goal, colleges and universities are required to follow the principles of reasonable requirements, clear responsibilities, and job matching in the establishment of positions for young teachers 'participation in education management, and to develop operational, long-term, scientific, and clear job responsibilities.

\section{B. Perfecting the Evaluation System of Training System for Young Teachers}

Teaching effect is the most important basis for evaluating and measuring the educational level of higher education. Taking the teaching effect as the core, we should formulate an authoritative and scientific evaluation system for young teachers' participation in education management in colleges and universities. In terms of authoritativeness, when formulating the evaluation system for young teachers' participation in education management in colleges and universities, college level is required to determine the corresponding responsible units, coordinate various functional departments on the basis of fully listening to the opinions of the department, and make rules and promote the corresponding work. We should respect the characteristics of different disciplines and specialties, and fully stimulate the initiative and creativity of departments. Under the unified leadership of the colleges, the departments should organize and implement the 
evaluation system. In terms of scientificity, we can adopt a compound evaluation system combining with multiple evaluation methods to evaluate young teachers' participation in the education management in colleges and universities. We must do a good job for self-evaluation, department evaluation, peer evaluation and student evaluation, start from a fair and just standpoint, consider the particularity of management work, avoid simple "indicators" assessment, and establish a scientific and authoritative appraisal mechanism through continuous exploration and practice.

\section{Forming an Incentive Guarantee System for the Training System of Young Teachers}

"Human social history is always just a history of their individual development, regardless of whether they realize it or not." ${ }^{5}$ P532. To encourage young teachers in colleges and universities to actively participate in the education management in colleges and universities, we must strengthen organizational security from the perspective of maintaining and guaranteeing the development of young teachers. We must organically integrate young teachers' participation in education management with the growth and progress of young teachers themselves. In the management work, we must strengthen targeted guidance to improve the management level and service awareness of young teachers; in education work, we must intensify the teaching exchange, education and training for young teachers to enhance the teaching level and scientific research level of young teachers; in the advance of work, relevant departments should promptly respond to the concerns of young teachers and take care of the needs of young teachers. In addition, colleges and universities should further improve the incentive and guarantee system in accordance with the requirements of the central government, so that young teachers can bring the experience of education management with their personal growth and development.. We must develop a special program, so that young teachers who are outstanding in the education management in colleges and universities can use it boldly and give full play to their expertise in different positions. To reinforce the reward and recognition, it should not only give preference to the individual treatments and working conditions, but also should give great support in promotion, professional title appraisal, individual career development, and create good atmosphere for young teachers' participation in education management of colleges and universities in the campus.

\section{CONCLUSION}

The level of development of higher education is an important indicator of a country's development level and development potential. To achieve the great rejuvenation of the Chinese nation, the status and role of education cannot be ignored. From the perspective of long-term development, colleges and universities should base on the growth and development of young teachers, formulate a scientific and long-term training system for young teachers, and encourage young teachers to participate in the education management in colleges and universities. Young teachers should deeply

\footnotetext{
Selections of Marx and Engels, volume 4[M]. Beijing: People's
}

Publishing House, 1995. comprehend the historical responsibility and mission they have undertaken, cultivate and exercise their abilities and talents in different posts such as education and management, constantly improve their own teaching and scientific research level, and dedicate our wisdom and strength to the great rejuvenation of the nation in this great era.

\section{REFERENCES}

[1] Xi Jinping. Put ideological and political work through the whole process of education and teaching and create a new situation in the development of higher education in China [N]. People's Daily, 2016-12-09.

[2] Xi Jinping. Secure a Decisive Victory in Building a Moderately Prosperous Society in All Respects and Strive for the Great Success of Socialism with Chinese Characteristics for a New Era-Delivered at the 19th National Congress of the Communist Party of China [N]. People's Daily, 2017-10-28.

[3] Xi Jinping. Put ideological and political work through the whole process of education and teaching and create a new situation in the development of higher education in China [N]. People's Daily, 2016-12-09.

[4] Opinions on Strengthening the Construction of Young Teachers in Colleges and Universities issued by Ministry of Education, Organization Department, Propaganda Department, National Development and Reform Commission, Ministry of Finance, Ministry of Human Resources and Social Security of the People's Republic of China. [Z]. Teachers. No.10[2012].

[5] Selections of Marx and Engels, volume 4[M]. Beijing: People's Publishing House, 1995. 